\section{THE ROLE OF THE FAMILY IN CHILDREN'S EMOTIONAL SOCIAL DEVELOPMENT}

\section{PERAN KELUARGA DALAM PERKEMBANGAN SOSIAL EMOSIONAL ANAK}

\author{
Hafizah Delyana', Mudjiran' \\ ${ }^{1}$ STKIP PGRI Sumatera Barat \\ ${ }^{2}$ Universitas Negeri Padang \\ 3hafizahdelyana@gmail.com \\ 4mudjiran.unp@gmail.com
}

Jurnal Pendidikan Luar Sekolah

http://kolokium.ppj.unp.ac.id/

Jurusan Pendidikan Luar Sekolah

Fakultas IImu Pendidikan

Universitas Negeri Padang

Sumatera Barat, Indonesia

Volume 8, Nomor 2, 2020

DOI: $10.24036 /$ kolokium-pls.v8i2.423

Received 20 July 2020

Approved 17 August 2020

Published 30 October 2020

\begin{abstract}
Social emotional development of children is the development of behavior in children where children are asked to adjust to the rules that apply in the community. Thus, social-emotional development is one aspect of development that is very important for every child because this is one of the determining factors for their success in the future. This can be realized through the process of forming good social and spiritual emotions so that children will be able to develop their potential to the maximum. Thus, families need to pay attention to the process of child development so that it runs optimally. This research is a literature study. The purpose of this study is to explain; 1) the theory of social emotional development, 2) the factors that influence children's social emotional development, 3) the role of the family in the social emotional development of children, and 4) learning activities to optimize the social emotional development of children. The explanation of the four points discussed above will greatly assist parents and teachers in understanding and improving children's social emotional abilities.
\end{abstract}

Keywords: Family, Social, Emotional, Children

\begin{abstract}
ABSTRAK
Perkembangan sosial emosional anak merupakan perkembangan perilaku pada anak dimana anak diminta untuk menyesuaikan diri dengan aturan-aturan yang berlaku di masyarakat. Dengan demikian, perkembangan sosial emosional merupakan salah satu aspek perkembangan yang sangat penting bagi setiap anak karena merupakan salah satu faktor penentu keberhasilan mereka di masa depan. Hal ini dapat diwujudkan melalui proses pembentukan emosi sosial dan spiritual yang baik agar anak dapat mengembangkan potensinya secara maksimal. Dengan demikian, keluarga perlu memperhatikan proses tumbuh kembang anak agar berjalan dengan optimal. Penelitian ini merupakan studi kepustakaan. Tujuan dari penelitian ini adalah untuk menjelaskan; 1) teori perkembangan sosial emosional anak, 2) faktor-faktor yang mempengaruhi perkembangan sosial emosional anak, 3) peran keluarga dalam perkembangan sosial emosional anak, dan 4) kegiatan pembelajaran untuk mengoptimalkan perkembangan sosial emosional anak. Penjelasan keempat poin yang dibahas di atas
\end{abstract}


akan sangat membantu orang tua dan guru dalam memahami dan meningkatkan kemampuan sosial emosional anak.

Kata Kunci: Keluarga, Sosial, Emosional, Anak

\section{PENDAHULUAN}

Pendidikan informal adalah proses yang berlangsung sepanjang usia sehingga setiap orang memperoleh nilai dan pengetahuan yang bersumber dari pengalaman hidup sehari-hari dan pengaruh lingkungan keluarga. Untuk mendukung keberhasilan seorang anak, maka sejak kecil anak perlu menguasai berbagai kemampuan terutama kemampuan sosial emosional yang baik, karena menurut (Goleman, 1995) keberhasilan hidup seseorang lebih ditentukan oleh kemampuan emosionalnya dibandingkan dengan kemampuan intelektual. Kemampuan sosial emosional merupakan landasan bagi perkembangan kemampuan anak dalam berinteraksi dengan lingkungannya secara lebih luas. Dalam berinteraksi dengan orang lain, individu tidak hanya dituntut untuk mampu berinteraksi secara baik dengan orang lain, tetapi terkait juga didalamnya bagaimana ia mampu mengendalikan emosi yang ada di dalam dirinya secara baik. Ketidakmampuan individu mengendalikan dirinya dapat menimbulkan berbagai masalah sosial emosional dengan orang lain. Pada perkembangan sosial emosional anak, keluarga memiliki peranan penting dalam memberikan pendidikan yang tepat dan terarah agar tercipta generasi yang baik secara social emosional. Apabila perkembangan mereka terabaikan dan pembentukan pribadi mereka dilakukan secara tidak terarah, maka mereka akan menjadi masalah bagi keluarga dan masyarakat. Pendidikan yang terjadi di dalam keluarga akan menentukan sikap dan mental anak dalam berinteraksi dengan lingkungannya. Kekokohan pondasi mental dan kejiwaan pada fase awal akan menjadi filter dalam menghadapi berbagai persoalan hidupnya di kemudian hari.2 Keluarga sebagai lembaga terkecil di dalam masyarakat diharapkan mampu menyiapkan mental anak dalam menghadapi hidupnya pada masa mendatang. Apabila didikan anak dalam keluarga baik dan terarah, maka kelak anak akan tumbuh dewasa sebagai manusia yang baik dan bermanfaat bagi masyarakat.(Qaimi, 2000) Untuk mempersiapkan generasi yang baik tersebut tidaklah mudah. Orangtua sebagai pendidik di lingkup keluarga harus memiliki pengetahuan tentang perkembangan emosional anak dan juga harus mengetahui kewajibannya dalam mendidik anak. Permasalahan sosial emosional ini bila dibiarkan begitu saja akan berkembang menjadi permasalahan yang lebih luas dan kompleks karena anak akan berkembang ke arah yang lebih buruk, terbentuknya kepribadian yang tidak baik dan berakibat munculnya perilaku-perilaku negatif yang tidak diharapkan.

\section{METODE}

Metode penelitian yang digunakan dalam pengumpulan informasi adalah dengan menggunakan studi pustaka.Metode studi pustaka atau studi literatur adalah mengumpulkan informasi dari buku-buku dan referensi lainnya yang terkait dengan masalah dan tujuan riset. Buku-buku dan literatur lain adalah sebagai sumber data yang akan diolah dan dianalisis oleh peneliti. Penelitian dilakukan dengan mengumpulkan sumber kepustakaan untuk mendapatkan informasi/keterangan yang bersifat teoritis. 


\section{PEMBAHASAN}

\section{Teori perkembangan sosial emosional}

Perkembangan sosial yaitu perkembangan tingkah laku anak dalam menyesuaikan diri dengan aturan-aturan yang berlaku di masyarkat tempat anak berada. Dapat juga diartikan sebagai proses belajar untuk menyesuaikan diri menjadi suatu kesatuan dan saling berkomunikasi dan bekerja sama. (Yusuf, 2004a). Perkembangan aspek sosial merupakan memeroleh kemampuan berperilaku yang sesuai dengan tuntutan sosial dan mampu bersosialisasi dengan memerlukan tiga proses sebagai berikut anak-anak harus menyukai orang dan aktivitas sosial, jika mereka berhasil melakukan mereka akan dapat menyesuaikan diri dengan baik dan akan diterima sebagai anggota kelompok. Secara bahasa sosial berarti sesuatu yang berkenaan dengan orang lain atau masyarakat. Sosial juga bisa berarti suka memperhatikan kepentingan umum, seperti suka menolong, menderma, dan sebagainya. Sedangkan emosi secara bahasa berarti luapan perasaan yang berkembang; keadaan dan reaksi psikologis dan fisiolagis seperti kegembiraan, kesedihan, keharuan, kecintaan yang bersifat subjektif. Pada konteks psikologi, emosi diartikan sebagai gejala psikofisiologis yang menimbulkan efek pada persepsi, sikap dan perilaku. Emosi dalam pemakaian kita sehari-hari sangat berbeda dengan pengertian emosi dalam psikologi. Emosi dalam pemakain sehari-hari mengacu pada ketegangan yang terjadi pada individu sebagai akibat dari tingkat kemarahan yang tinggi. Menurut (Mashar, 2011), emosi adalah suatu keadaan yang kompleks pada diri organisme, yang meliputi perubahan secara badaniah dalam bernapas, detak jantung, perubahan kelenjar dan kondisi mental, seperti keadaan menggembirakan yang ditandai dengan perasaan yang kuat dan biasanya disertai dengan dorongan yang mengacu pada suatu bentuk perilaku.

Berdasarkan berbagai pengertian diatas, maka sosial emosi dapat diartikan sebagai perbuatan yang disertai dengan perasaan-perasaan tertentu yang melingkupi individu di saat berhubungan dengan orang lain. Jadi perkembangan sosial emosi pada anak usia dini yaitu perubahan perilaku yang disertai dengan perasaan-perasaan tertentu yang melingkupi anak usia dini saat berhubungan dengan orang lain.

Teori Perkembangan Sosial dikembangkan oleh Erik Erikson. Erik Erikson lahir Frankfurt, Jerman pada tahun 1902. Ia adalah seorang penganut aliran Psikoanalisis dari Sigmund Freud yang kemudian menjadi neofreudian (psikoanalisa yang didasarkan pada hubungan sosial). Teorinya ini disebut dengan Teori Psikosoaial. Ia berpendapat bahwa setiap individu berjuang melakukan pencarian identitas diridalam tiap tahap kehidupannya. Hal ini dikarenakan identitas merupakan pengertian dan penerimaan, baik untuk diri sendiri maupun masyarakat (Duvall, E. M \& Miller, 1985). Menurut Erikson, masyarakat memiliki peranan yang sangat penting dalam perkembangan psikososial seorang individu. Peranan ini dimulai dari pola asuh orangtua hingga aturan atau budaya masyarakat (Duvall, E. M \& Miller, 1985). Berikut ini merupakan tahapan perkembangan psikososial seorang individu (Desiningrum DR, 2012): (1) Kepercayaan vs Ketidakpecyaan (usia 0-1 tahun) Pada tahap ini harus belajar menumbuhkan kepercayaan pada oranglain, contohnya anak kepada ibunya. Jika anak tidak berhasil dalam tahap ini, maka ia akan jadi anak yang mudah takut dan rewel; (2) Otonomi vs Malu dan Ragu-Ragu (usia 1-3 tahun) Pada tahap ini anak mulai belajar kemandirian (otonomi), seperti makan atau minum sendiri. Jika anak tidak berhasil pada tahap ini karena selalu ditegur dengan kasar ketika proses belajar, maka anak menjadi pribadi 
akan yang pemalu dan selalu ragu-ragu dalam melakukan sesuatu; (3) Inisiatif vs Rasa Bersalah (usia 3-6 tahun) Pada tahap ini anak mulai memiliki gagasan (inisiatif) berupa ide-ide sederhana. Jika anak mengalami kegagalan pada tahap ini, maka ia akan terus merasa bersalah dan tidakmampu menampilkan dirinya sendiri; (4) Kerja Keras vs Rasa Inferior (usia 6-12 tahun) Pada tahap ini anak mulai mampu berkerja keras untuk menyelesaikan tugas-tugasnya dengan baik. Jika pada tahap ini anak tidak berhasil, maka kedepannya anak akan menjadi pribadi yang rendah diri (minder) dan tidak mampu menjadi pemimpin; (5) Identitas vs Kebingungan Identitas (usia 12-19 tahun) Pada tahap ini individu melakukan pencarian atas jati dirinya (identitasnya). Jika ia gagal pada tahp ini, mak ia akan merasa tidak utuh; (6) Keintiman vs Isolasi (usia 20-25 tahun) Pada tahap ini individu mulai keintiman psikologis dengan oranglain. Jika ia gagal pada tahap ini, maka ia akan merasa kosong dan terisolasi; (7) Generativitas vs Stagnasi (usia 26-64 tahun) Pada tahap ini individu memiliki keinginan untuk menciptakan dan mendidik generasi selanjutnnya. Jika ia tidakberhasil dalam tahap ini, maka ia akan merasa bosan dan tidak berkembang; (8) Integritas vs Keputusan (usia 65 tahun ke atas). Pada tahap ini individu akan menelaah kembali apa saja yg sudah ia lakukan dan ia capai dalam hidupnya. Jika ia berhasil pada tahp ini, maka ia akan mencapai integritas (penerimaan akan kekurarangan diri, sejarah kehidupan, dan memiliki kebijakan), sebaliknya jika ia gagal, maka ia akan merasa menyesal atas apa yg telah terjadi dalam hidupnya.

Selain dari itu, menurut (Turner, J.S \& Helms, 1995) pola perilaku sosial anak dapat dilihat dari empat dimensi, yaitu : (1) anak dapat bekerjasama (cooperating) dengan teman, (2) anak mampu menghargai (altruism) teman, baik dalam hal menghargai milik, pendapat, hasil karya teman atau kondisi-kondisi yang ada pada teman, (3) anak mampu berbagi (sharing) kepada teman. Apakah anak mampu berbagi sesuatu yang dimilikinya kepada teman, mau mengalah pada teman dan sebagainya, dan (4) anak mampu membantu (helping others) orang lain. Hal ini tidak hanya ditunjukkan dalam hubungannya dengan teman sebaya tetapi juga dengan orang dewasa lainnya.

Selanjutnya, teori perkembangan emosional dipopulerkan oleh Maslow. Abraham Maslow lahir di Brooklyn pada tahun 1908 dan meninggal di Rusia pada tahun 1970. Awalnya Maslow mempelajari teori behaviorisme dan melakukan banyak percobaan dalam bidang tersebut. Namun, setelah Pearl Harbour diserang oleh Jepang, ia beralih ke bidang psikologi Hall, 1985 (Hildayani, 2009). Ia merasa bahwa psikologi hanya memandang manusia dari segi negatifnya, sehingga ia melihat psikologi dari sisi yang lain, yaitu lebih ke sisi positifnya. Maslow berpendapat bahwa manusia tidak hanya harus melawan kesedihan, ketakutan, dan hal negatif lainnya, tetapi manusia juga harus mencari kebahagian dan kesejahteraan. Maslow menyatakan bahwa pada dasarnya manusia itu baik, tidak jahat (We are basically good, no evil). Menurut Maslow ada 4 hal yang harus ditekankan mengenai hal ini, yaitu; a. manusia memiliki struktur psikologis yang beranalagi sperti struktur fisik, yaitu kebutuhan (needs), kapasitas (capacities), dan kecenderungan (tendencies) yang didasari oleh keadaan genetis; b. perkembangan yang sehat diharapkan selalu melibatkan aktualisasi dari karakteristik; c. keadaan patologis setiap manusia berasal dari penyangkalan (denial), frustasi (frustration), atau memutar (twisting) keadaan manusia; dan d. manusia memiliki keinginan dan kemampuan aktif untuk mencapai kesehatan mental dalam perkembangan aktualisasi diri. Menurut Maslow seorang individu dapat berhubungan dengan dunia melalui dua cara, yaitu D-realm atau deficiency (kekurangan) dimana manusia bertahan hidup dengan cara 
berusaha memenuhi seluruh kebutuhan dasarnya. Setelah kebutuhan dasarnya terpenuhi, maka manusia akan beranjak ke tahap B-realm atau being (menjadi), dimana manusia memiliki motivasi untuk mencari aktuailisasi dirinya dan pengayaan dari keberadaannya.

Maslow mencetuskan sebuah teori yang berkaitan dengan motivasi manusia dalam memenuhi kebutuhannya. Teori ini disebut sebagai Hierarki Kebutuhan Maslow, yang meliputi: (1) Kebutuhan fisiologis, yaitu kebutuhan fisik yang paling dasar seperti rasa lapar, haus, dan lelah; (2) Kebutuhan akan rasa aman, yaitu kebutuhan akan rasa keselamatan, kestabilan, proteksi, struktur, keteraturan, hukum, batasan, dan bebas dari rasa takut; (3) Kebutuhan memiliki dan cinta, yaitu kebutuhan memiliki hubungan yang harmonis dengan oranglain, seperti keluarga, pasangan, anak, dan teman; (4) Kebutuhan rasa percaya diri, yaitu kebutuhan akan perasaan kuat, menguasai sesuatu, kompetensi, dan kemandirian. Juga kebutuhan akan perasaan dihormati oleh oranglain, status, ketenaran, dominansi menjadi orang penting, serta harga diri dan penghargaan; (5) Kebutuhan aktualisasi diri dan metaneeds, yaitu kebutuhan untuk mengaktualisasikan diri dengan mengembangkan diri dan melakukan sesuatu yang dikuasai. Contohnya adalah seorang musisi yang menciptakan lagu dan seorang pengusaha yang sukses. Kebutuhan aktualisasi diri ini memayungi metaneeds, dimana sebagian metaneeds ini merupakan merupakan kebutuhan dasar yang harus dipenuhi.

(Hildayani, 2009) mengungkapkan bahwa ada 4 aspek perkembangan sosial-emosi pada anak usia dini: (1) Perkembangan pemahaman diri, Pada masa kanak-kanak awal (4-6 tahun) mereka memandang dirinya secara berlebihan karena mereka lebih mendasari penilaian dirinya pada kemajuan yang mereka buat dalam berbagai kegiatan yang dilakukan daripada membandingkan kemampuan mereka dengan teman-teman sebayanya; (2) Perkembangan hubungan sosial, Area utama perkembangan hubungan sosial adalah pertemanan. Dalam pertemanan, anak ingin bisa bermain sebanyak mungkin dengan temannya; (3) Perkembangan kemampuan mengatur diri sendiri, Kemampuan individu untuk mengatur diri sendiri berkembang seiring dengan perkembangan sosial individu; (4) Perkembangan perilaku sosial, Perilaku sosial merupakan kegiatan yang berhubungan dengan orang lain.

\section{Faktor-faktor yang Mempengaruhi Perkembangan Sosial Emosional Anak}

Berkaitan dengan hubungan interaksi antara satu individu dengan individu lainnya, manusia juga pada umumnya saling membutuhkan. Berkaitan dengan hal itu perkembangan sosial manusia dipengaruhi oleh beberapa faktor yaitu: (1) Keluarga, Keluarga merupakan lingkungan pertama yang memberikan pengaruh terhadap berbagai aspek perkembangan anak, termasuk perkembangan sosialnya. Kondisi dan tata cara kehidupan keluarga merupakan lingkungan yang kondusif bagi sosial anak.; (2) Kematangan, Bersosialisasi memerlukan kematangan fisik dan psikis. Untuk mempertimbangkan dalam proses sosial, memberi dan menerima pendapat orang lain, memerlukan kematangan intelektual dan emosional; (3) Status sosial ekonomi, Kehidupan sosial banyak dipengaruhi oleh kondisi atau status kehidupan keluarga dalam lingkungan masyarakat.Sehubungan hal itu, dalam kehidupan anak senantiasa "menjaga" status sosial anak dan ekonomi keluarganya. Dalam hal tertentu, maksud "menjaga status sosial keluarganya" itu mengakibatkan menempatkan dirinya dalam pergaulan yang tidak tepat; (4) Pendidikan, Pendidikan merupakan proses sosialisasi anak yang terarah. Pendidikan dalam arti luas harus diartikan bahwa perkembangan 
anak dipengaruhi oleh kehidupak keluarga, masyarakat dan kelembagaan; (5) Kepastian mental: emosi dan intelegensi, Kemampuan berfikir mempengaruhi banyak hal, seperti kemampuan belajar, memecahkan masalah, dan berbahasa.Anak yang berkemampuan intelektual tinggi akan berkemampuan bahasa secara baik. Pada kasus tertentu, seorang jenius atau superior, sukar untuk bergaul dengan kelompok sebaya, karena pemahaman mereka telah setingkat dengan kelompok umur yang lebih tinggi. Sebaliknya kelompok umur yang lebih tinggi (dewasa) tepat "menganggap" dan "memperlakukan" mereka sebagai anak-anak. (Bahri Djamarah, 2006).

(Hurlock, 1999) dan Lazarus (1991) dalam (Mashar, 2011), menyatakan bahwa perkembangan emosi pada anak dipengaruhi oleh dua faktor penting, yaitu: (1) Maturation atau kematangan, (Hurlock, 1999) dalam (Mashar, 2011), memandang pentingnya faktor kematangan pada masa kanak-kanak terkait dengan masa krisis perkembangan (critical period), yaitu saat-saat ketika anak siap menerima sesuatu dari luar.Kematangan yang telah dicapai dapat dioptimalkan dengan pemberian rangsangan yang tepat. Contoh dalam perkembangan emosi, pengendalian pola reaksi emosi yang diinginkan perlu diberikan kepada anak guna menggantikan pola emosi yang tidak diinginkan, sebagai tindakan preventif; (2) Faktor lingkungan belajar, Faktor lingkungan dalam proses belajar, berpengaruh besar untuk perkembangan emosi, erutama lingkungan yang berada paling dekat dengan anak khususnya ibu atau pengasuh anak. Thompson dan Lagatutta dalam (Mashar, 2011), menyatakan bahwa perkembangan emosi anak usia dini sangat dipengaruhi oleh pengalaman dan hubungan keluarga dalam setiap hari, anak belajar emosi baik penyebab maupun konsekuensinya.

Menurut (Akilasari, Yekti, 2015), salah satu faktor Yang mendukung perkembangan sosial emosional anak adalah Keluarga. Pada ilmu pendidikan, keluarga menjadi lingkungan pendidikan yang pertama dan utama. Dengan demikian, dapatlah dikatakan lingkungan keluarga memiliki peran yang utama dalam menentukan perkembangan sosial dan emosi anak usia dini dikemudian hari dan untuk kehidupan selanjutnya yang akan mereka jalani, dan dilingkungan keluarga ini lah anak pertama kalinya menerima pendidikan dari orang tuanya atau orang terdekatnya. Orang tua mereka merupakan pendidik bagi mereka pola asuh orang tua, sikap, serta situasi dan kondisi yang sedang melingkupi orang tua dapat memberikan pengaruh yang sangat besar terhadap perkembangan sosial dan emosi anak.

\section{Peran keluarga terhadap perkembangan sosial emosional anak}

Keluarga adalah lingkungan yang sangat dekat dengan anak, keluarga memiliki peranan dan fungsi yang besar dalam mendukung perkembangan anak secara optimal. Hurlock dalam (Mashar, 2011) menyatakan bahwa sikap orangtua yang positif akan memberikan dampak yang positif dan baik terhadap perilaku anak. Tetapi sebaliknya jika sikap orangtua yang kurang memberikan sikap acuh pada anak maka anak akan cenderung tidak bertanggung jawab serta memiliki perilaku yang kurang baik. Seperti dalam penelitian (Nermeen E El Nokali, Heather J Bachman, 2010) bahwa anak dari orangtua yang terlibat lebih tinggi dalam fungsi sosial akan lebih sedikit memiliki masalah perilaku. (Indra Kusuma Fuad \& Sutadji Eddy, 2014) menyatakan bahwa dukungan orang tua merupakan bentuk peran orang tua dalam meningkatkan pencapaian kompetensi peserta didik. 
Keterlibatan orangtua dalam pendidikan anak sangat dibutuhkan untuk pemenuhan fasilitasi kebutuhan lingkungan belajar anak dan keikutsertaan orangtua dalam program pembelajaran anak di sekolah. Keterlibatan orangtua telah muncul sebagai salah satu topik yang paling penting dan sering dibicarakan di kalangan pendidikan. Keterlibatan orangtua dalam pendidikan anak di sekolah sangat membantu guru dalam memberikan stimulus yang tepat untuk perkembangan anak. Kemitraan dapat meningkatkan program dan iklim sekolah, menyediakan layanan keluarga, meningkatkan keterampilan orangtua dan kepemimpinan, menjalin hubungan dengan orangtua lain di sekolah dan dalam masyarakat, dan membantu guru dalam pekerjaan mereka.

Orangtua perlu mengetahui tentang keadaan dan perilaku anak mereka selama berada di sekolah, dan manfaat untuk gurunya sendiri dapat berkomunikasi dengan orangtua siswa tujuannya untuk memahami perilaku anak selama berada di rumah. Epstein (2009 dalam (Mashar, 2011) menyatakan terdapat tiga konteks dalam teori overlapping of influence yaitu keluarga, sekolah dan masyarakat. Model ini terdiri dari praktek-praktek yang sekolah, keluarga dan masyarakat lakukan secara terpisah untuk mempengaruhi anak-anak dalam belajar, pengembangan dan prestasi akademik. Steven (Mashar, 2011) menunjukkan bahwa anak yang berhasil memiliki dukungan akademik yang kuat dan keterlibatan dari anggota keluarga. Keterlibatan orangtua di sekolah akan menjadi kepuasan tersendiri untuk orangtua khususnya karena mereka menjadi percaya diri dalam mengasuh anak-anak mereka di rumah dan menambah wawasan serta pengalaman dalam pengasuhan, sehingga mereka bisa menjalankan tugasnya sebagai orangtua.

(Hurlock, 1999) mengatakan bahwa perkembangan sosial adalah kemampuan seseorang dalam bersikap atau berperilaku dalam berinteraksi dengan unsur sosialisasi di masyarakat yang sesuai dengan tuntunan sosial. Perkembangan sosial merupakan pencapaian kematangan dalam hubungan sosial. kemampuan sosial anak dapat diperoleh dari berbagai kesempatan dan pengalaman bergaul dengan orang-orang dilingkungannya. Kebutuhan berinteraksi dengan orang lain telah dirasakan sejak usia enam bulan, ketika anak sudah mampu mengenal lingkungannya. (Suparno, 2010) dalam penelitiannya menyatakan bahwa perilaku sosial adalah tindakan perilaku yang dilakukan oleh seseorang dalam hubungan antar individu maupun inter individu dengan dirinya sendiri yang dapat dilihat dan dapat diamati dalam kehidupan sehari-hari. (Yusuf, 2004) menyatakan bahwa perkembangan sosial dapat juga diartikan sebagai proses belajar untuk menyesuaikan diri terhadap norma-norma atau aturan-aturan kelompok, moral, atau adat istiadat, meleburkan diri menjadi suatu kesatuan dan saling berkomunikasi serta bekerja sama.

Salah satu unsur perkembangan sosial adalah perkembangan kepribadian. Peran orang tua adalah menyediakan banyak peluang bagi anak-anak untuk membangun kepercayaan, membuat berbagai macam pilihan serta merasakan sukses dari pilihan yang mereka buat sendiri. Selain itu, membantu anak-anak untuk mengenali kebutuhan dan perasaan mereka sendiri merupakan hal yang penting di dalam membangun kepercayaan anak. Anak harus merasakan bahwa gagasannya adalah gagasan yang baik dan orang lain menghormati gagasan itu. (Yuliani N. S, 2008). Peran keluarga dalam perkembangan sosial anak akan berhasil jika orang tua dapat memberikan pelayan dan pilihan yang baik dan benar kepada anaknya untuk kebutuhan perkembangan dan menumbuhkan kepercayaan dirianaknya. 
(Haryanti, 2014) menyatakan bahwa proses interaksi anak dengan orang lain dan teman sebaya maupun dengan orang yang lebih dewasa merupakan suatu bentuk perkembangan sosial pada anak. Manusia sebagai makhluk sosial yang tidak akan mampu hidup sendiri, mereka membutuhkan interaksi dengan manusia lainnya karena interaksi sosial merupakan kebutuhan kodrati yang dimiliki oleh manusia. Hawari (Suyadi, 2010) mengatakan bahwa emosi anak berbedabeda, perbedaan tersebut dipengaruHa oleh sikap, cara, dan kepribadian orangtua dalam memelihara, mengasuh, dan mendidik anaknya. Dalam perspektif lain pebedaan itu dikarenakan oleh faktor genetis, lingkungan dan diasuh oleh orangtua yang berlatar belakang pendidikan atau keilmuan yang berbeda. Namun adapun persamaan di antara sekian perbedaan emosi tersebut. Persamaan itu adalah terstimulasinya emosional setiap anak jika diberikan stimulus. Oleh karena itu, dalam rangka mencerdaskan emosi anak pemberian stimulus melalui permainan harus disesuaikan dengan tingkat perkembangan sosial emosional anak.

(Goleman, 2002) menyatakan bahwa orang yang secara emosionalnya cakap maka orang tersebut dapat menangani perasaannya sendiri dan mampu membaca dan memahami perasaan orang lain. Orang yang memiliki kecerdasan emosional yang tinggi adalah mereka yang mampu mengendalikan diri, memelihara dan memacu motivasi untuk terus berupaya dan tidak mudah menyerah, mampu mengendalikan dan mengatasi stres, mampu menerima kenyataan. Senada dengan Mayer \& Salovey dalam penelitian (Nermeen E El Nokali, Heather J Bachman, 2010) yang menyatakan bahwa individu yang memiliki kecerdasan emosi yang tinggi memiliki hubungan sosial yang lebih baik, dapat memecahkan masalah emosional lebih cepat dan lebih mudah, kuat dalam kecerdasan verbal, sosial, dan kurang terlibat masalah perilaku.

\section{Kegiatan pembelajaran untuk mengoptimalkan perkembangan sosial emosional anak}

Hurlock (1991) dalam (Mashar, 2011), mengungkapkan proses belajar yang menunjang perkembangan emosi terdiri dari beberapa, yaitu: (1) Belajar dengan cara meniru (learning by imitation), Dengan mengamati hal-hal yang membangkitkan emosi tertentu orang lain, anakanak bereaksi dengan emosi dan metode ekspresi yang sama dengan orang-orang yang diamati; (2) Belajar dengan mempersamakan diri (learning by identification), Disini anak hanya meniru orang yang dikagumi dan mempunyai ikatan emosional yang kuat.; (3) Belajar melalui pengkondisian (conditioning), Metode ini berhubungan dengan aspek ransangan, bukan dengan aspek reaksi. Pengkondisian terjadi dengan mudah dan cepat pada tahun-tahun awal kehidupan mereka, anak kecil kurang mampu menalar, kurang pengalaman untuk menilai situasi secara kritis, dan kurang mengenal betapa tidak rasionalnya reaksi mereka; (4) Pelatihan (training), Belajar dibawah bimbingan dan pengawasan, terbatas pada aspek reaksi. Kepada anak diajarkan cara bereaksi yang dapat diterima jika suatu emosi terangsang; (5) Belajar dengan coba-coba, Anak belajar coba-coba untuk mengekspresikan emosi dalam bentuk prilaku yang memberikan pemuasan terbesar kepadanya dan menolak prilaku yang memberikan pemuasan sedikit.

Kecerdasan sosial-emosional pada anak tidak dimiliki secara alami tetapi harus ditumbuhkan dan dikembangkan oleh orangtua maupun oleh pendidik. Dalam mengembangankan sosial-emosional anak diperlukan metode yang bisa digunakan untuk 
mengembangkan aspek tersebut, berikut beberapa metode yang dapat digunakan. (1) Keteladanan, Pembelajaran dengan melalui keteladanan adalah pembelajaran melalui contohcpntoh yang baik, dapat diterima oleh masyarakat, dan sesuai dengan standar dan sistem nilai yang berlaku. Metode ini efektif diterapkan pada anak melalui proses pencontohan dan peniruan. Kegiatan keteladanan dapat ditularkan kepada anak usia dini untuk mengembangkan sosial-emosional antara lain sebagai berikut: (1) keteladanan dalam beribadah, seperti adab dalam berdoa dan solat; (2) keteladanan yang berhubungan dengan oranglain, seperti cara menyapa, cara meminta, cara berkomunikasi, dan tata karma;(3) keteladanan dalam bekerja dnmenyelesaikan masalah, seperti bersabar, bersemangat, dan displin; (4) teladan dalam berpakaian dab berbusana, seperti berpakaian ke sekolah, berpakaian melayat orang yang meninggal, dan berpaaian beribadah; (5) teladan gaya hidup, yaitu tidak boros, sederhana, suka menabung, dan lain-lain; (6) teladan cara belajar, seperti pemanfaatan waktu belajar, adab belajar, dan sebagainya; (7) teladan dalam menyikapi lingkungan, seperti membuang sampah pada tempatnya, membersihkan kamar atau kelas sendiri, dan sebagainya. Selain dari contoh-contoh di atas masih banyak teladan lain yang bisa dilakukan, sesuai dengan perkembangan budaya dan kebutuhannya. Pendekatan ini sangat penting karena anak memiliki daya imitasi yang tinggi. (Nurjannah, 2017); (2) Metode Mendongeng atau Bercerita, Mendongeng adalah suatu kegiatan yang bersifat professional, karena membutuhkan keahlian khusus, seperti mengatur gaya dan intonasi ketika bercerita agar membuat anak tertarik untuk mendengarkan dan memahami cerita atau dongeng yang disampaikan. Nilai yang terkandung dalam dongeng pun harus di bungkus dengan sebaik mungkin, baru setelah selesai mendongengkan pendidik menjelasakan nilai tersebut. Cerita yang disampaikan dengan baik akan mampu mengajak anak memasuki sebuah "dunia baru" dan membuat membangkitkan kehidupan yang bary dab menambah nilai seni anak (Efendi, 2006). Melalui kegiatan mendongeng ini pendidik dapat membentuk sikap anak melalui nilai, pesan, atau sikap yang terkandung dalam dongeng yang disampaikan. Selain itu juga, melalui pengenalan dan pemahaman nilai-nilai yang ada dalam kegiatan mendongeng ini, anak akan terdorong untuk terus berinteraksi dengan lingkungan dan oranglain (Efendi, 2006); (3) Bermain Kooperatif, Menurut Nugraha (2004) dalam (Wardany, 2016) bermain kooperatif adalah permainan yang dilakukan oleh sekolompok anak, dimana setiap anak mendapatkan peran dan tugasnya masing-masing yang harus dilakukan untuk mencapai tujuan bersama. Hal ini sejalan dengan hasil penelitian Kibtiyah (2006) dalam (Wardany, 2016), efek dari bermain kooperatif menunjukkan bahwa anak yang tumbuh dengan sering bermain, secara sosial ia lebih aktif, lebih kreatif, lebih kaya akan kosa kata, lebih lancar dalam berbicara, dan lebih bahagia dalam menjalankan tugas-tugasnya jika dibandingkan dengan anak yang tidak bermain. Kemudian menurut hasil penelitian Kartika (2015) dalam (Wardany, 2016), bermain kooperatif dapat meningkatkan perilaku kerjasama dan membantu anak untuk tidak berperilaku agresif. Selain itu, bermain jenis ini dapat meningkatkan rasa penghargaan pada teman sebaya, pada diri sendiri, dan ketrampulan sosial lainnya; (4) Bermain Pura-Pura atau Bermain Peran, Kegiatan bermain peran ini dapat dilakukan sejak anak berusia 3 tahun. Kegiatan bermain ini melibatkan unsur imajinasi dan daya imitasi pada perilaku orang dewasa. Contohnya, bermain sekolah-sekolahan, pasar-pasaran, dan dokter-dokteran. Dalam permainan ini anak menggunaka imajinasi untuk menghasilkan gagasannya sendiri, seperti sebatang ranting yang dianggap sebagai sebuah pedang. Imajinasi anak juga menggambarkan 
keinginan, perasaan, dan pandangan anak terhadap lingkungan sekitarnya (Mulyani, 2014); (5) Outbound, Outbound merupakan suatu kegiatan bermain yang dilakukan di alam terbuka dengan berdasarkan prinsip experiential learning (belajar melalui pengalaman langsung) yang bersifat kreatif, edukatif, serta rekreatif, dan petualangan dijadikan sebagai media penyampaian materi dengan anak dilibatkan dalam seluruh kegiatan yang dilakukan (Isbayani, Sulastri, dan Tirtayani (2015) dalam (Istiqomah, 2016). Melalui kegiatan ini anak belajar mengenali kemampuan dan kelemahan dirinya sendiri, serta tertantang untuk mengembangkan kemampuan yang dimilkinya (Istiqomah, 2016). Jenis permainan outbound yang dapat dipilih diantaranya adalah permainan halang rintang, estafet tongkat, dan moving water.

\section{KESIMPULAN}

Keluarga bagi seorang anak merupakan lembaga pendidikan non formal pertama, di mana mereka hidup, berkembang, dan matang. Di dalam sebuah keluarga, seorang anak pertama kali diajarkan pada pendidikannya. Dari pendidikan dalam keluarga tersebut anak mendapatkan pengalaman, kebiasaan, ketrampilan berbagai sikap dan bermacam-macam ilmu pengetahuan. Keluarga memiliki peranan penting dalam meningkatkan kualitas sumber daya manusia. Pendidikan moral dalam keluarga perlu ditanamkan pada sejak dini pada setiap individu. Walau bagaimana pun, selain tingkat pendidikan, moral individu juga menjadi tolak ukur berhasil tidaknya suatu pembangunan. Faktor-faktor yang mempengaruhi perkembangan social emosional anak yaitu : keluarga, kematangan, status sosial ekonomi, pendidikan, emosi, mental dan lingkungan belajar. Dari factor-faktor tersebut sangat berperan penting dalam perkembangan sosial emosional anak usia dini. Adapun kondisi yang mempengaruhi perkembangan social emosional anak yaitu: kondisi kesehatan, suasana rumah, cara mendidik anak, hubungan dengan anggota keluarga,hubungan dengan teman sebaya, perlindungan yang berlebihlebihan,aspirasi orang tua dan bimbinngan. Jika Semua keluarga/orangtua memfokuskan perannya kepada perkembangan anak dapat memberikan dampak/keyakinan yang kuat dan besar terhadap perkembangan perilaku, sikap dan pribadi anaknya tersebut dengan baik dan benar. Kesungguhan orang tua dalam memberikan peran sebagai wujud tanggungjawab keluarga atas perkembangan anak maka menjadikan anaknya dengan mudah menjadi orang yang sukses.

\section{DAFTAR RUJUKAN}

Akilasari, Yekti, dkk. (2015). Faktor Keluarga, Sekolah, dan Teman Sebaya Pendukung Kemampuan Sosial Anak Usia Dini. Bandar Lampung: Fakultas Keguruan dan Pendidikan Universitas Lampung Bandar Lampung.

Bahri Djamarah, S. (2006). Guru dan Anak Didik dalam Interaksi Edukatif. Jakarta: Rineka Cipta.

Desiningrum DR. (2012). Buku Ajar Psikologi Perkembangan Anak. Semarang: UPT UNDIP Press Semarang.

Duvall, E. M \& Miller, C. M. (1985). Marriage and Family Development 6th ed. New York: Harper \& Row Publisher.

Efendi, M. (2006). Psikopedagogik Anak Berkelainan. Jakarta: Bumi Aksara. 
Goleman, D. (1995). Kecerdasan Emosi: Mengapa Emotional Intelligence Lebih Tinggi. Daripada IQ. Jakarta: Gramedia Pustaka Utama.

Goleman, D. (2002). Kecerdasan Emosional Untuk Mencapai Puncak Prestasi. (Alex Tri Kantjono Widodo, Ed.). Jakarta: PT. Gramedia Pustaka.

Haryanti, S. (2014). Pemahaman Kompetensi Parenting Terhadap Perkembangan Sosial Anak. Jurnal Pendidikan Dan Pemberdayaan Masyarakat, 1(1).

Hildayani, R. dkk. (2009). Psikologi Perkembangan Anak. Jakarta: Universitas Terbuka.

Hurlock, E. . (1999). Psikologi Perkembangan: Suatu Pendekatan Sepanjang Rentang Kehidupan. (Istiwidayati \& Soedjarwo, Ed.) (Edisi Keli). Jakarta: Erlangga.

Indra Kusuma Fuad, \& Sutadji Eddy, T. (2014). Kontribusi Dukungan Orang Tua, Penguasaan Pengetahuan Dasar, Dan Motivasi Berprestasi Terhadap Pencapaian Kompetensi Kejuruan. Jurnal Kependidikan: Penelitian Inovasi Pembelajaran, 44(1).

Istiqomah, dkk. (2016). Peningkatan Perkembangan Sosial dan Emosional Melalui Kegiatan Outbound pada Anak Kelompok B di TK Asy-Syafa'ah Jember Tahun Pelajaran 2015/2016. Jurnal Edukasi Unej, 3(2).

Mashar, R. (2011). Emosi anak Usia Dini dan Strategi Pengembangan. Jakarta: Kencana.

Mulyani, N. (2014). Upaya Meningkatkan Perkembangan Sosial Emosional Anak Usia Dini, $3(2)$.

Nermeen E El Nokali, Heather J Bachman, E. V.-D. (2010). Parent Involvement and Children's Academic and Social Development in Elementary School. Journal of Educational Psychology University of Pittsburgh, 81(3), 988-1005.

Nurjannah. (2017). Mengembangkan Kecerdasan Sosial Emosional Anak Usia Dini melalui Keteladanan. Jurnal Bimbingan Konseling Dan Dakwah Islam, 4(1).

Qaimi, A. (2000). Buaian Ibu Diantara Surga dan Neraka-Peran Ibu dalam Mendidik Anak. Bogor: Cahaya.

Suparno, dkk. (2010). Pengembangan Model Modifikasi Perilaku Sosial Melalui Media Belajar Berkonsep Konvergensi Bagi Anak Autis. Jurnal Kependidikan, 40(2), 201214.

Suyadi. (2010). Psikologi Belajar Anak Usia Dini. Yogyakarta: PEDAGOGIA.

Turner, J.S \& Helms, D. . (1995). Life Span Development. Fifth Edition. Tokyo: Harcourt Brace College Publishers.

Wardany, dkk. (2016). Aktivitas Bermain Kooperatif Meningkatkan Perkembangan SosialEmosional Anak. Bandar Lampung: FKIP Universitas Lampung.

Yuliani N. S. (2008). Konsep Dasar Pendidikan Anak Usia Dini, hlm.72; Carol Seefeldt \& Barbara A. Wasik, Early Childhood Education, terj. Pius Nasar, Pendidikan Anak Usia Dini. Jakarta: Indeks.

Yusuf, S. (2004a). Psikologi Perkembangan Anak \& Remaja. Bandung: Remaja Rosdakarya.

Yusuf, S. (2004b). Psikologi Perkembangan Anak \& Remaja. (PT. Remaja Rosdakarya, Ed.). Bandung. 